\title{
A Study of Changes in Direction, Focusing on Discipline Methods and Classroom Management in Korean Schools
}

\author{
Sang-Chul LEE $\mathrm{L}^{\dagger}$ Maurice Lineman \\ ( ${ }^{\dagger}$ Pusan National University $\cdot$ Kyungsung University)
}

\section{한국 학교에서의 훈육방법과 교실경영 변화 방향에 관한 연구 \\ 이 상 철 ${ }^{\dagger} \cdot$ 모리스 린네만 \\ (†부산대학교. 경성대학교)}

\begin{abstract}
본 연구의 목적은 2011년 3월 한국 학교에서의 체벌이 법적으로 금지된 이후 훈육방법과 교실경 영의 변화 방향을 탐색하는 것이다. 연구의 목적을 달성하기 위하여, 첫째, 한국과 해외 국가의 체벌 에 대한 경향을 살펴보았다. 체벌은 한국 사회, 가정, 그리고 교육기관에서 오랜 역사를 가진 전통적 인 훈육 방식으로 특히 군사부일체, 스승의 그림자는 밟지 않는다, 사랑의 매 등과 같이 스승의 권위 를 근거로 행하여져 왔다. 2012년 현재 세계 국가들 중에서 59\%가 체벌을 금지하고 있으며, 특히 $\mathrm{OECD} 34$ 개국 중에서는 29 개국이 체벌 금지, 한국을 포함한 4 개국이 부분적 금지 등으로 대부분의 국가들이 체벌을 금지하고 있다. 둘째, 한국과 해외 국가의 교실경영 방법을 비교해 보았다. 한국에 서는 문제행동의 지도방법이 벌점부여 등과 같이 단순하고 소극적이며, 교육적 효과에 대한 검증 부 족, 문제행동 지도방법에 대한 사회적 합의부족 등과 같은 한계가 있었다. 해외 국가에서는 문제행동 의 체계적 유형화, 문제행동의 원인 연구, 문제행동 지도방법 체계화 및 위계화, 문제행동의 예방과 지도방법의 효과 연구 등이 활발하였다. 따라서 체벌 금지 이후 한국 교실경영에 대한 시사점으로, 문제행동 지도방법에 대한 심도있는 논의, 문제행동 예방 및 지도방법에 대한 효과 연구, 교원양성 및 현직 교육에 문제행동 지도방법 교육, 학생 문제행동 지도에 대한 사회적 합의 등을 제안하였다.
\end{abstract}

Key words : 훈육, 교실경영, 체벌, 문제행동

\section{I . INTRODUCTION}

Discipline in Korean schools historically is based on traditional practices, derived from family and education inputs and over time, these practices have been incorporated in modern Korean schools. The origin of corporal punishment in Korean schools was in the Confucian schools of the Joseon Dynasty (1392-1910). In these schools, when students misbehaved, they were hit with a rod, designated as the "Rod of Love". Documents from the Joseon Dynasty state that the average number of hits received by a student was forty (Jeong, 1987). The students were commonly hit on the back of the calf over the bulk of the calf muscle. While the number of hits may have decreased, the student is still hit in that location. As well, other places of contact have emerged over time,

† Corresponding author : 051-510-2637, 1sc2203@hanmail.net 
including the soles of the feet (a practice no more in use) and the buttocks.

In Confucian schools of the Joseon Dynasty, "Seodang (village school), Hyanggyo, and Seong-Kyun-Kwan, the use of corporal punishment for infractions was a common practice throughout Korea. The teacher, or "Seuseung" who was for the most a Confucianist scholar, handed out punishment. The idea came from traditional proverbs, used throughout Korean history. Proverbs such as "매 끝 에 정든다, 매에는 장사 없다, 귀한 자식 매로 키 운다, 매로 키운 자식 효성 있다, 서당 아이들은 초달에 매여 산다 (The rod and student grow intimate with each other, A strong man (Hercules) can endure everything but a rod)." The outcome being that the rod was used as a form of corporal punishment by both the parent and the teacher.

In recent times, corporal punishment has continued both at school and at home in the belief that it is necessary to improve the student achievement levels. However, following the democratic movement of the 1980s, which moved the country towards globalization, this implementation of corporal punishment remained the same. The practice of corporal punishment did not evolve as society evolved. Rather, the practice has expanded to include, forcible night classes (up to $11 \mathrm{p} . \mathrm{m}$. in high school), hairstyle regulations, restrictions of students human rights, and the inability to choose their own life paths (Yoo, 2011).

Prior to the prohibition of corporal punishment in Korean schools in March 2011, the Enforcement Decree of the Elementary and Secondary Education Act, as defined by the Supreme court of Korea, stated that corporal punishment can be only be used as a last measure for a transgression of the rules. Thus, the use of corporal punishment in Korean schools was allowed, yet limited by the
Supreme Court of Korea. However, some teachers use this rule to validate any form of corporal punishment. In a 2010 survey on the necessity of corporal punishment, performed by the Korean Federation of Teachers'Association (2010) it was found that $15.5 \%$ of teachers were in opposition and $82.2 \%$ were in support of corporal punishment. In this same survey, it was noted that $90.5 \%$ felt that corporal punishment was necessary while only 9.5\% thought that corporal punishment was not warranted. This point of view was supported by surveys posted by Yang (2011) who found that $57.6 \%$ of instructors felt that punishment was necessary and by Jeong (2011) who found that $68.4 \%$ of teachers felt that corporal punishment was required in school, because they believed that the only effective method of punishment was corporal punishment.

Globally, the practice of corporal punishment, when used as a classroom management tool, is undergoing a decline. The movement towards the abolition of corporal punishment in schools began in Poland in 1783 (Global Initiative, 2012). This has since continued with more states removing Corporal punishment from their education disciplinary profiles. Internationally, 117 nation states have totally removed corporal punishment from the education system, while another seven have enforced limited prohibition, while seventy-four nation states formally enforce corporal punishment within their education systems (Global Initiative, 2012).

Comparatively, in the majority of western education systems, the concept of classroom management through discipline control and punishment has evolved over time to the point where physical punishment no longer is practiced. While some countries may condone the use of physical punishment, the actual application is strictly controlled. In the 
United States, corporal punishment is still accepted in 19 states, while 32 states have emplaced a ban/prohibition on corporal punishment; however, in practice American schools prohibit the use of corporal punishment as a means of student discipline (Global Initiative, 2012). Comparatively, in Canada, the use of corporal punishment has been legally banned at the national and provincial level, to the point where a teacher can be prosecuted for touching a student.

It is our contention that the practice of physical discipline in Korean schools should be altered in such a way as to be comparable to the western education system. The reason is that the current state of discipline in Korean schools is detrimental to the students' involvement with learning. To achieve this we will provide a history of corporal punishment within Korea, and then compare this to the eradication of corporal punishment at the global level and use this as the foundation for developing a plan to establish a classroom management program for Korean schools based on other more effective classroom management programs from other countries.

\section{II . CORPORAL PUNISHMENT AS THE DISCIPLINE METHOD IN KOREAN AND SCHOOLS WORLDWIDE}

\section{Definitions of corporal punishment, discipline, and classroom management}

Before identifying issues on school physical punishment in Korean education, it is necessary to specify a definition of discipline, school physical punishment and classroom management, which are the key words of this research. Discipline is defined as "teaching and nurturing integrity or morality" (The Korean Language Society, 1992) and interpreted from the educational and developmental approaches (Park, 2001). On the other hand, corporal punishment is defined as "imposing pain to the physical body as one of punishment to correct misbehaviors" (Kwon, 1999) and is considered one of the disciplinary methods that has been handed down to modern Korea from the past. Therefore, discipline is regarded as being a higher conceptual level than school physical punishment. However, at the same time, it identifies educational implications for students based on educational and developmental aspects rather than non-educational or human rights perspectives. Moreover, discipline is defined as "actions that facilitate the development of self-control, responsibility, and character"(Savage \& Savage, 2010) and are interpreted as counteractions against misbehavior to manage classroom more effectively in the west. Fundamentally, it is similar to the definition in Korea where the emphasis is on educational aspects. The concept of classroom management in the west, which is similar to discipline in Korea, is defined as "teachers actions and strategy to manage and control learners by facilitating effectively learning experience of learners and to plan teaching syllabus and classroom environment and to solve problems in terms of maintaining order of classroom"(Doyle, 1986). This is understood to mean that classroom management focuses on the prevention of misbehavior. In particular, Savage and Savage (2010) and Allen (2010) understand discipline and classroom management to be a planned strategy that facilitates learning, growth and learner development. Therefore, the concept of discipline, school physical punishment, and classroom management are summarized; school physical punishment is seen 
as a traditional discipline method in Korean society to correct misbehavior by imposing physical pain, and discipline and classroom management is "a teacher's strategy to counteract and prevent learners misbehaviors to achieve educational objectives such as growth and development of learners". In this study, the researchers approached discipline and classroom management from the same meaning and used discipline together with classroom management according to this construct.

\section{Corporal punishment as the discipline method in Korean schools}

1) History of corporal punishment in Korea

Historically, during the Joseon Dynasty, the King, Teacher and Father were of equal stature (군 사부일체) in the eyes of the student and the student, therefore, should never stand in the shadow of the teacher, because he was not good enough (스승의 그림자는 밟지 않는다). During the period of Japanese colonization, and the 1961-1987 military regime this pattern of responsibility and top-down control still existed and was actually put to use as a tool for controlling students, and during these two military regimes (the Japanese and the Korean military dictatorships that followed), as a means for population control as well.

As noted earlier, during the period of the Joseon Dynasty, the king as titular commander of the country, was the most important person in the nation. According to the Kyonggukdaejon, that is Joseon Dynasty law, the punishment for a crime was corporal punishment (Yun, 2005). Corporal punishment was seen as a viable method for altering behavior. The next step down in the management of society fell to the city magistrate, who would then enforce the king's wishes and get the king's due with respect to punishment for transgression. The next person on the ladder for societal control was the teacher, who used corporal punishment in the classroom as a means of student control. Finally, the terminal person in the chain of societal control, during the Joseon Dynasty, was the father. The father would use corporal punishment as a means of affecting the behavior of his children and even the wife for transgressions.

While this chain of command (responsibility) is descriptive of the society, it does not necessarily relate to the education system, except in the role of deterrence. However, since the education system is a smaller version of the larger social system, it is possible that the education system was a mirror for the social system. In Korea, the basis for this structural organization of power lies in historical figures and paintings where the implement of corporal punishment is visible next to the teachers' desk. During the Joseon Dynasty, there are written records of corporal punishment being used to manipulate and control students and their behavior during the instruction period (Jeong, 1987). The length of the Joseon Dynasty, at 600 years, makes it one of the longest running dynasties in the world, and the longest ruling Confucianist Dynasty. What is important here is that the practice of corporal punishment, under the Joseon Dynasty, was a direct means of education control and student manipulation. Yulgok Lee Yi a famous Korean scholar from the Joseon Dynasty wrote "Beat on the calf to whip to student commit mistake" in the School Model (Nation culture propulsion committee, 1982), a book written during the Joseon Dynasty regarding classroom and student control. In reality this is translated as "hit a student, who makes a mistake, on the calf" the purpose of which is to reinforce their mental training and control. The 
implication is that beating a student on his calf muscle (a form of corporal punishment still practiced in Korea) was actually seen as an effective tool in student behavioral management. In reality, the use of physical pain was a means of getting the student to improve their grades.

Classroom control fell to the teacher, while the control of house activities fell to the father. Chodal (초달) is the name of the practice whereby the teacher, or father, would beat the student on the calf muscles for any infraction of the rules. This was used as a physical means of "adjusting" the students behavior when they had done something wrong. The painting by Kim Hong Do (1745-1806, 18th century) provides a good example of the tool used where the whip (a cane made from a tree or bamboo plant) would be used to hit the student for failure to achieve a satisfactory grade in their work. This practice was not only limited to the lower education levels. In Seong-Kyun-Kwan (a university founded during the Joseon Dynasty), the following punishment clauses were found to exist in the school regulations.

"for writing improvisational poetry which is not poetic in nature the penalty is 40 blows on the calf, slandering a teacher will result in 100 blows to the calf, general daily infractions will incur less blows on the calf muscle" (Jeong, 1987)

In Korean history, the Joseon Dynasty gave way to Japanese colonialism in the late 1870 s with full annexation occurring in 1910 . During the period of annexation, the control of the education system fell under the Japanese and punishment in the school system exhibited changes. However, these changes were motivated more by perceived racial supremacy than a desire to alter a child's behavior in the classroom. The ideological beliefs of the Japanese, which saw them as a better people, led to the idea that other Asian nations were inferior to the Japanese and the result was that any Korean student who went to school would be treated badly by both the Japanese teacher and the other Japanese students.

2) Practice in Korea, pre-corporal punishment ban

The use of corporal punishment was dependent on the response group. The three response groups in the education system in Korea are teachers, the parents, and the students.

In $1983,84 \%$ of teachers in the school system used corporal punishment (Choi 1983 as cited in Lee 1995); however, there was no distinction regarding the ratio of actual use versus non-use. Even though this data is lacking, it is possible to surmise that the actual use of corporal punishment, at the time, was at least equal to if not greater than $84 \%$ simply because it was legally acceptable at the time. In 2010, the law was changed to reflect a growing understanding of students' rights and changes in Korean society. The result was that, while $70 \%$ of teachers believed corporal punishment should be required, only $35 \%$ of teachers actually practiced its use, and $65 \%$ of teachers had abolished it from the classroom as a method of classroom disciplinary action (Jeong, 2011), see $<$ Table 1>. Prior to the implementation of the ban on corporal punishment more than $72.7 \%$ of middle school teachers in middle and high school used corporal punishment; however, following the implementation of the ban this number dropped to $14.1 \%$ (Yang, 2011) however, this percentage is in question. According to a study by Sung et al. (1999) <Table 2>, the parents group had a different response, relative to the teachers. In the parental group $70.9 \%$ of parents believed that corporal punishment should be utilized in schools, while 
<Table 1> Change in Teachers point of view of corporal punishment

\begin{tabular}{|c|c|c|c|c|c|c|c|}
\hline \multirow{3}{*}{$\begin{array}{l}\text { Elementary } \\
\text { school }\end{array}$} & \multirow[b]{2}{*}{ Year } & \multicolumn{2}{|c|}{$\begin{array}{l}\text { Requirement for } \\
\text { corporal punishment }\end{array}$} & \multicolumn{2}{|c|}{$\begin{array}{l}\text { Actual use of corporal } \\
\text { punishment (current) }\end{array}$} & \multicolumn{2}{|c|}{$\begin{array}{l}\text { Lack of corporal } \\
\text { punishment (current) }\end{array}$} \\
\hline & & $\begin{array}{l}\text { Choi } \\
\text { (1983) }\end{array}$ & $\begin{array}{l}\text { Jeong } \\
(2011)\end{array}$ & $\begin{array}{l}\text { Choi } \\
(1983)\end{array}$ & $\begin{array}{l}\text { Jeong } \\
\text { (2011) }\end{array}$ & $\begin{array}{l}\text { Choi } \\
\text { (1983) }\end{array}$ & $\begin{array}{l}\text { Jeong } \\
\text { (2011) }\end{array}$ \\
\hline & $\%$ & $84 \%$ & $70 \%$ & $84 \%$ & $35 \%$ & $16 \%$ & $65 \%$ \\
\hline \multirow{2}{*}{$\begin{array}{l}\text { Middle and } \\
\text { High school }\end{array}$} & Year & $\begin{array}{c}\text { Kim } \\
(1993)\end{array}$ & $\begin{array}{l}\text { Yang } \\
(2011)\end{array}$ & $\begin{array}{l}\text { Yang } \\
(2011)\end{array}$ & $\begin{array}{l}\text { Yang } \\
\text { (2011) }\end{array}$ & $\begin{array}{l}\text { Yang } \\
(2011)\end{array}$ & $\begin{array}{c}\text { Yang } \\
(2011)\end{array}$ \\
\hline & $\%$ & $85.7 \%$ & $57.6 \%$ & $72.7 \%$ & $14.1 \%$ & $27.3 \%$ & $85.9 \%$ \\
\hline
\end{tabular}

Note. In 2011, the law was changed to reflect the adoption of students'rights within the school system. This value is determined by the actual use value, since data is lacking for the period in question

$25.9 \%$ felt that it should be used only when necessary, and the remaining $3.2 \%$ felt that it should never be used. In a study performed by Kim and $\operatorname{Kim}$ (2006), 7.8\% believed it to be necessary all the time, $65.6 \%$ emphasized light corporal punishment, $21.1 \%$, it would be better not to use it, but it is acceptable, and $5.5 \%$ believed it should never be used. In a similar study in 2008 (Yoo et al., 2008) found that $6.4 \%$ believed it to be necessary, $58.9 \%$ felt that it should be light corporal punishment, $28.5 \%$ said it should be used in a limited manner, while $6 \%$ said it should never be used. Correspondingly, Namgung \& Woo (2010) in a study of parental understanding of the use of corporal punishment $6.5 \%$ of parents said always necessary, $60 \%$ stated only light corporal punishment, $26 \%$ stated it is better to not use corporal punishment, and $6.9 \%$ said it should never be used. That is, society controls the mode of discipline and the state and parents support its use in the school system, because of a long period of practice and history both in education and at home.

In 2011 (Namgung and Woo, 2011), changed the survey to account for the separation of corporal punishment (direct) to a more restrictive frame of indirect punishment (education punishment) so any
<Table 2> Parental concept of the use of corporal punishment

\begin{tabular}{|c|c|c|c|c|c|c|}
\hline & $\begin{array}{c}1999 \\
\text { (Sung et } \\
\text { al.) }\end{array}$ & $\begin{array}{c}2006 \\
(\mathrm{Kim} \& \\
\text { Kim) }\end{array}$ & $\begin{array}{c}2008 \\
\text { (Yoo et } \\
\text { al.) }\end{array}$ & $\begin{array}{c}2010 \\
\text { (Namgun } \\
\mathrm{g} \& \\
\text { Woo) }\end{array}$ & $\begin{array}{c}2011^{*} \\
\text { (Namgun } \\
\mathrm{g} \& \\
\text { Woo) }\end{array}$ & $\begin{array}{c}2012 * \\
\text { (Namgun } \\
\text { g et al.) }\end{array}$ \\
\hline Necessary & \multirow{2}{*}{$70.9 \%$} & $7.8 \%$ & $6.4 \%$ & $6.5 \%$ & \multirow{2}{*}{ NA } & \multirow{2}{*}{ NA } \\
\hline Light use & & $65.6 \%$ & $58.9 \%$ & $60 \%$ & & \\
\hline Restricted use & $25.9 \%$ & $21.1 \%$ & $28.5 \%$ & $26 \%$ & \multirow{2}{*}{ NA } & \multirow{2}{*}{ NA } \\
\hline Never & $3.2 \%$ & $5.5 \%$ & $6 \%$ & $6.9 \%$ & & \\
\hline $\begin{array}{l}\text { Approval of } \\
\text { indirect } \\
\text { punishment }\end{array}$ & NA & NA & NA & NA & $75.1 \%$ & $84.8 \%$ \\
\hline $\begin{array}{l}\text { Rejection of } \\
\text { indirect } \\
\text { punishment }\end{array}$ & NA & NA & NA & NA & $23.8 \%$ & $14.2 \%$ \\
\hline
\end{tabular}

Note. following the ban on corporal punishment in 2011, the designation became indirect and direct punishment; NA means not applicable

comparisons would be invalid. However, in 2011, there was an increase in the level of indirect punishment (education punishment) 75.1\% as compared to a decrease in the belief for direct punishment (corporal punishment) 23.8\%. In 2012, Namgung et al. found that these rates had changed to $84.8 \%$ in favor of indirect punishment and $14.2 \%$ were against indirect punishment.

The students had an even greater difference in their responses to the use of corporal punishment $<$ Table 3>. In 2002, Kim found that $61.8 \%$ of students thought that corporal punishment was necessary. Students were the recipients of corporal punishment at different levels. $24.2 \%$ of students received punishment often, while $58.6 \%$ of students were only sometimes punished, with $15.8 \%$ of students saying they were rarely punished and $1.4 \%$ of students said the teacher never punished them (Kim, 2002). Ahn (2007) in a study of elementary students found that $78 \%$ of students had been subject to corporal punishment and $22 \%$ had never experienced it.

Park and Yeon (2003) performed a study on how secondary school students perceived the use of corporal punishment. Of all students surveyed, 
$43.6 \%$ believed that corporal punishment is necessary, while $56.5 \%$ stated that it is wrong to use corporal punishment. Alternatively, 72.6\% had been subject to corporal punishment, while 27.4\% had never experienced it (Park \& Yeon, 2003). Yang (2011) found that more than $63.4 \%$ of students experienced corporal punishment in middle and high school prior to the ban on corporal punishment; however, after the implementation of the ban this number dropped to $29 \%$.

$<$ Table 3> Change in Students point of view towards corporal punishment

\begin{tabular}{|c|c|c|c|c|c|}
\hline \multirow[b]{2}{*}{ Years } & \multirow{2}{*}{$\begin{array}{c}\begin{array}{c}\text { Requirement } \\
\text { for corporal } \\
\text { punishment }\end{array} \\
\text { Kim }(2002)\end{array}$} & \multicolumn{2}{|c|}{$\begin{array}{l}\text { Actual use of corporal } \\
\text { punishment (current) }\end{array}$} & \multicolumn{2}{|c|}{$\begin{array}{l}\text { Lack of corporal } \\
\text { punishment (current) }\end{array}$} \\
\hline & & Kim (2002) & Ahn (2007) & Kim (2002) & Ahn (2007) \\
\hline Elementary & $61.8 \%$ & $\begin{array}{l}\text { (24.2\%+58.6 } \\
\%) 82.8 \%\end{array}$ & $78 \%$ & $\begin{array}{l}\text { (15.8\%+1.4 } \\
\%) 17.2 \%\end{array}$ & $22 \%$ \\
\hline Year & $\begin{array}{l}\text { Park and } \\
\text { Yeon }(2003)\end{array}$ & $\begin{array}{l}\text { Park and } \\
\text { Yeon (2003) }\end{array}$ & $\begin{array}{r}\text { Yang } \\
(2011)\end{array}$ & $\begin{array}{l}\text { Park and } \\
\text { Yeon (2003) }\end{array}$ & Yang (2011) \\
\hline $\begin{array}{l}\text { Middle and } \\
\text { high school }\end{array}$ & $43.6 \%$ & $72.6 \%$ & $29.0 \%$ & $27.4 \%$ & $71 \%$ \\
\hline
\end{tabular}

3) Legal code governing the use of corporal punishment in Korea

Within Korea, the development of legal practices regarding the student discipline has its foundation in the Comprehensive Education act of 1947. This act was legal until Enforcement Decree of the Elementary and Secondary Education Act of 1998. Article 31 of Enforcement Decree of the Elementary and Secondary Education Act related to the enforcement of punishment in schools and Article 31 Clause 7 read:

"In the event of providing the guidance under the provisions of the main part of Article 18(1) of the Act, the head of the school shall use the method of discipline and admonishment so not to inflict physical pain to the students except during unavoidable situations."

This implies restrictive permission to use corporal punishment in the school system, only as a final choice, and that the enforcer should be the principal of the school.

Following a series of controversies over corporal punishment, the 1998 law came under review. In March 2011, a newly revised Article 31 was put into effect by the Korean government. The revised law reads:

"In the event of providing the guidance as provided under the provisions of the main part of Article 18(1) of the Act, according to this school regulation, use the method of discipline and admonishment, but not use method of (to) inflict pain to the students using a tool or a part of the body etc."

This firmly states that the use of a tool or a part of the enforcers' body cannot be used, in any way, as a method for inflicting pain as a mode of corporal punishment for the student. In essence, the law now states that the use of corporal punishment is banned in all Korean schools, from elementary through to secondary schools. Instead, it implies that the new system should be based on the use of indirect nonviolent punishment forms. While, the teachers using corporal punishment decreased, the practice of corporal punishment still occurs within the Korean education system. The ban on corporal punishment, while it might be a legal constraint, has not produced a large decrease in the use of corporal punishment (Yeonhap News, 2011).

Following the 2011, March revision of Enforcement Decree of the Elementary and Secondary Education Act, Article 31.8 (Punishment of Students Etc.): In the event of providing the guidance as provided under the provisions of the main part of Article 18 (1) of the Act. According to this regulation, it is permissible to use the method of discipline and admonishment, but not to 
use the method of punishment to inflict physical pain to the students using a tool, or body part etc.

\section{Corporal punishment as the discipline method in schools around the world}

Globally corporal punishment has a varied history. Historically, the use of corporal punishment had been used throughout the whole world. As implied by a Western saying, "Spare the rod and spoil the child", corporal punishment has been a disciplining tool with importance in the Western educational setting as same as in Korea. However, over time it has, in most parts of the world fallen into disuse, at least in recent times. Corporal punishment, as a method of behavioral modification as used in classroom management, is increasingly being removed from the classroom and the school on the precept that its use is a violation of students'rights.

The first nation to ban the use of corporal punishment in schools was Poland in 1783. Since then a steadily increasing number of countries have banned the use of corporal punishment in schools. While the practice has been banned in a number of countries, a large number still promote the use of corporal punishment within their education systems. In figure, it can be identified that 117 have established full prohibition of corporal punishment in schools, 7 have some form of limited use of corporal punishment, and 74 still use corporal punishment in the school, accordingly showing that the ratio of countries prohibiting school corporal punishment reaches $59 \%$. To look into the status of corporal punishment in school in a more detailed manner, all of Europe having introduced prohibition of corporal punishment ban it lawfully. Out of 34 members of Organization for Economic
Co-operation and Development (OECD), an organization of economically advanced countries, countries fully banning corporal punishment are 29 with 4 countries restrictively banning corporal punishment, while only Mexico legally accepts corporal punishment. Of the 4 countries restrictively using corporal punishment, only Australia and the USA, which are a federal system of states, are divided into explicitly corporal punishment in school prohibitive states and practicing states. Korea allows deliberate but methodically indirect infliction of pain to the extent of, for example, painful gesture (so-called 'punishment in educational discipline'), although disallowing direct punishment with physical force. Meanwhile, Chile explicitly bans physical punishment that may cause human injury (Global Initiative, 2012).

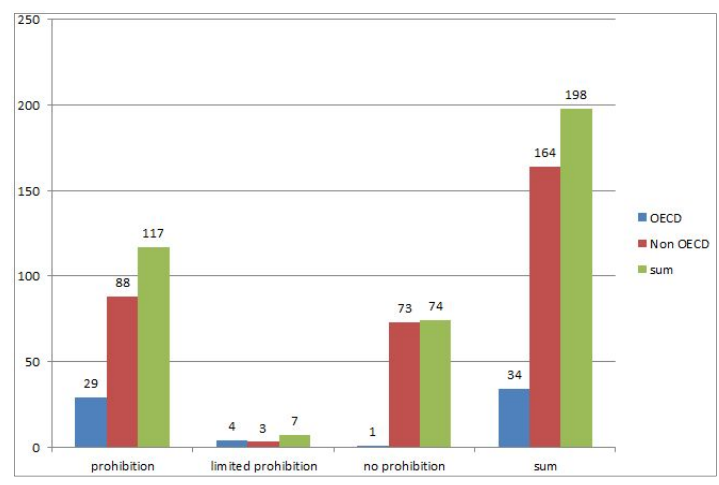

[Fig. 1] Number of schools exhibiting different prohibition levels of corporal punishment

Of these, two nations have been selected for evaluation of corporal punishment, one that has abolished corporal punishment, and one that still sanctions use of corporal punishment in the school system. They are respectively, Spain and the United States. Each will be discussed in depth as to the laws and the enactment of those laws, which prohibit, restrict, or allow the use of corporal 
punishment in the school and will be able to find the implication about the assignment after the banned corporal punishment in Korea schools.

Spain abolished corporal punishment in 1985 . According to Article 17 of Royal Decree 732/1995, the statutory framework regulating social relations in schools, states that "all pupils have the right to respect for their physical and moral integrity, and may in no circumstances be subjected to humiliating or degrading treatment". Comparatively, article 43.2 prohibits "punishments inconsistent with the physical integrity and personal dignity of the pupil”. Furthermore, Under Organic Law 10/2002 on the Quality of Education, students have the right to be shown respect for their personal integrity and dignity and are protected against all physical or moral aggression (article 2.2). These laws make it a crime to impose any form of physical punishment on the students, under articles of law (Global Initiative, 2012).

The United States, unlike Spain, has a very different system. The individual states have greater say in how punishment is meted out. There is no prohibition of corporal punishment at the federal level for all levels of education under state care. The closest thing, at the federal level that could be used is the eighth amendment; however, in 1977 the supreme court in Ingraham v Wright, 430 U.S. 651 (1977) stated that the eighth amendment did not apply to schoolchildren. This left the enforcement of physical punishment up to the states. To begin with, the corporal punishment in school accepting and non-accepting status in public schools by state of the USA is presented in <Table 4>. In this Table, public schools in 31 states and the District of Columbia including New Jersey beginning in 1967 prohibit corporal punishment in school, where many states among them join the trend banning the from 1970s to 1990s. On the contrary, public schools in 19 states allow corporal punishment in their intramural settings, in which what is notable is that these states, being located in the southeastern and southwestern areas, are analyzed to be affected by cultural and religious attributes such as conservative politics and evangelical Protestantism (Dupper \& Dingus, 2008).

$\langle$ Table 4> Corporal punishment in U.S. public schools

\begin{tabular}{|c|c|c|}
\hline & state & total \\
\hline prohibition & $\begin{array}{l}\text { Alaska (1989), California (1986), Connecticut } \\
\text { (1989), Delaware (2003), District of Columbia } \\
\text { (1977), Hawaii (1973), Illinois (1993), Iowa } \\
\text { (1989), Maine (1975), Maryland (1993), } \\
\text { Massachusetts (1971), Michigan (1989), } \\
\text { Minnesota (1989), Montana (1991), Nebraska } \\
\text { (1988), Nevada (1993), New Hampshire (1983), } \\
\text { New Jersey (1967), New Mexico (2011), New } \\
\text { York (1985), North Dakota (1989), Ohio } \\
\text { (2009), Oregon (1989), Pennsylvania (2005), } \\
\text { Rhode Island (1977), South Dakota (1990), } \\
\text { Utah (2006), Vermon t(1985), Virginia (1989), } \\
\text { Washington (1993), West Virginia (1994), } \\
\text { Wisconsin (1988) }\end{array}$ & 32 \\
\hline permission & $\begin{array}{l}\text { Alabama, Arizona, Arkansas, Colorado, Florida, } \\
\text { Georgia, Idaho, Indiana, Kansas, Kentucky, } \\
\text { Louisiana, Mississippi, Missouri, North Carolina, } \\
\text { Oklahoma, South Carolina, Tennessee, Texas, } \\
\text { Wyoming }\end{array}$ & 19 \\
\hline
\end{tabular}

Note. From "Corporal punishment in U.S. public schools" by D. R. Dupper and A. E. M. Dingus, 2008, Children \& Schools, 30(4), p.250; U.S. states banning school corporal punishment

To further the description, three states, which have different practices regarding the use of Corporal punishment, were examined. New jersey, the first state to ban the use of corporal punishment, established legal code (Sec 18A:6-1) to define the practice. In this code it was stated that

"the use of physical force is exceptionally allowed in justifiable and inevitable cases under the extent authorized by one's job scope, stating, (1) to quell a disturbance, threatening physical injury to others, (2) to obtain possession of weapons or other dangerous objects upon the person or within the 
control of a pupil, (3) for the purpose of self-defense; and (4) for the protection of persons or property."

The next two states allow for the use of corporal punishment within schools, one with limited use and the other with full use.

Arizona has provided a procedural guideline document titled, "Pupil disciplinary proceedings". Furthermore, in Sec, 15-843 of its state laws, it allows the use of corporal punishment or physical force according to the disciplinary rules set out by the School District. This allows the practice as long as it does not infringe on the students constitutional rights. It does this by referring to;

(1) Procedures for the use of corporal punishment if allowed by the governing board, (2) Procedures for the reasonable use of physical force by certificated or classified personnel in self-defense, defense of others and defense of property.

The final state is Georgia, which in Sec 20-2-731 of its state laws provides the guidelines regarding the use of corporal punishment by each county and the education commission shall be based on;

(1) The corporal punishment shall not be excessive or unduly severe, (2) Corporal punishment shall never be used as a first line of punishment for misbehavior, (3) Corporal punishment must be administered in the presence of a principal or assistant principal, (4) The principal or teacher who administered corporal punishment must provide the child's parent.

The primary finding here is that the percentage of countries prohibiting corporal punishment is $59 \%$ globally, and principally includes European nations. The OECD nations are split with $85 \%$ prohibiting corporal punishment, implying that the ban of corporal punishment is strongly connected to economic ability, however, this need to be proved.
Secondarily, the reasons for banning corporal punihsment in New Jersey and Spain are correlated to human rights issues. Comparatively, in those states that utilize corporal punishment, there are legal guidelines on its use and the extent of punishment that can be applied.

\section{CLASSROOM MANAGEMENT IN KOREAN AND SCHOOLS WORLDWIDE}

One of the primary reasons for the use of corporal punishment in Korea is classroom management. However, the concept of corporal punishment in managing a classroom is tenuous. Better classroom management principles have to be provided to teachers as a means of controlling the classroom environment because in Korean classrooms, the principal cause for the use of corporal punishment is a student's misbehavior in the classroom (Ahn, 2007).

\section{Methods of classroom management in Korea}

How can classroom student behavior be modified without the use of corporal punishment? Currently in Korean schools, the process is simple, but there is no standard in its application. In order for teachers to have a viable and workable alternative to corporal punishment as a classroom management tool, the method of classroom management needs to be fleshed out in a more defined manner. This will enable teachers to be more organized in their application of discipline practices and let go of corporal punishment management techniques, and, more importantly positively impact student learning outcomes. Currently, in Korean schools, Park (2001) 
has categorized students' misbehaviors into 7 different types; (1) Classroom interference, (2) aggressive actions, (3) challenge to teachers' authority, (4) laziness, (5) violation of rules and process, (6) violation of community rules, (7) immoral behavior, and the principal causes for discipline issues are inappropriate question, sleeping, joking in class, chewing gum, etc (Kim, 2005a, 2005b). These are dealt with via the use of corporal punishment, ranging from verbal abuse to strong physical contact. These behavioral issues are also found in elementary schools; however, there are more infractions found in elementary schools (Kim \& Hwang 2009). While these infractions do not seem to be major, they do disrupt the class leading to decreased instructional effectiveness.

Teacher's counteractions against these types of misbehaviors are categorized by Park (1997); school physical punishment covers beating, physical pain, giving assignments, and mental suffering and materialistic compensation can be imposed. In addition, for spiritual approach, teachers can give learners opportunity to be touched by a good case, or counseling and conversation or self-reflection. Furthermore, a variety of activities can be used, such as disciplinary training activity, students' voluntary activities or teachers can act as a model.

Kim (2004) has divided discipline methods for individual and group misbehaviors; for individual misbehaviors, intentional ignorance, control learner's communication, reprimand, spiritual affection, stay after school, deprive of rights or advantages, punishment, school physical punishment, inform parents. While for group misbehaviors, teachers presentation as a model, democratic attitude, formulating classroom rules, spiritual affection, complements for other actions of learners, person-to-person conversation, school physical punishment and informing parents.

Based on a teacher-student survey, Sohn (2003) identified the following structure for dealing with misbehaviors: (1) Write an apology, (2) Student life assessment card, (3) Service in school, (4) Special education program, (5) Expulsion from school, (6) Limited to class participation, (7) Limited to break time, and (8) Do not send home after school.

Seoul Metropolitan Office of Education (2012) suggested the following instructions in its 2012 life education of school for students to prohibit the following school physical punishment. First, types of school physical punishment to be prohibited are; when punishment is used by tools, hands and feet, disciplinary punishment causing repetitive and continuous physical pain and compelling punishment among peer students. Secondly, alternative programs for school physical punishment are suggested; guidance inside classroom (order students standing at the rear of the classroom, or sitting on 'thinking chair'during the class), Time out guidance, Green Mileage System, voluntary work, work-oriented education, interview with parents. Third, are examples suggested by Ministry of Education, i.e. oral reprimand, isolation, counseling, special assignment, etc.

Furthermore, Jo et al. (2012) in an assessment of the new punishment protocols found the following; $51.1 \%$ of teachers felt that there was an increase in the level of disobedience on the part of the students, and $31.5 \%$ of teachers felt that order within the school system was collapsing. Comparatively, the parents and the students felt that there has been no change at $36.4 \%$ and $39.4 \%$ respectively. The teachers indicated the following change; modifications of teacher responses to issues with behavior $35.3 \%$ are more passive to student misbehaviors, $31.7 \%$ avoid conflict with students or 
parents, $17.2 \%$ find alternative methods for behavior modification, $11.2 \%$ utilize counseling as a method for behavioral control and alteration.

In short, the following points emerge while there are a variety of misbehaviors present in Korean schools. For example, noises during the class, violence to other students, challenging to teachers, violation of rules in class, to spit, stealing things other students and etc. A second factor is, in Korea, methods used to enforce discipline in the classroom are simple, passive methods that lack systematic application. Second, current guiding methods to misbehaviors are simple and passive: they lack systemicity (corporal punishment, demerit system, recording a roll book, caution, lie face down etc), and any verification of the effect has not been proven. Therefore, there is no guidance; nor is there any diversity of action based on the seriousness of the misbehavior. Third, there has been a lack of discussion regarding guiding methods following the ban on corporal punishment. Fourth, there has been no social consensus regarding alternative methods for discipline practices between all agents involved. This has resulted in a source of conflict between the specific groups involved.

\section{ALTERNATIVE METHODS OF CLASSROOM MANAGEMENT}

In other countries, methods of classroom management are diverse, with different classroom applications. In a survey conducted in 2004 (Public Agenda, 2004) it was found that $75 \%$ of teachers felt that disruptive behavior was the largest impediment to effective instruction. Comparatively, Guardino and Fullerton (2010) surveyed teachers regarding disruptive behavior in the classroom, and they learned that disruptive behavior was the most problematic issue for teachers. Levin \& Nolan (2007) identified the most common day-to-day disruptive behaviors: (1) verbal interruptions, (2) off-task behaviors, (3) physical movement intended to disrupt, (4) disrespecting the teacher. Further to this Charles (2011) describes 13 types of student misbehavior (1) Inattention, (2) Apathy; (3) Needless talk (4) Moving about the room; (5) Annoying others,; (6) Disruption, (7) Lying; (8) Stealing;. (9) Cheating; (10) Sexual harassment; (11) Aggression and fighting; (12) Malicious mischief; and (13) Defiance of authority.

Out of this developed a prevention and treatment program for effective classroom management including the misbehavior treatment. Using Jones \& Jones (2001), Emmer, Evertson \& Worsham (2003) designed a 5-step method for the control of student misbehavior that included the following points:

(1) nonverbal signaling to stop misbehavior,

(2) verbal warning for continued misbehavior,

(3) If behavior continues, the student and teacher enter a verbal contract regarding behavior

(4) continued misbehavior - the verbal contract becomes a written contract, create a behavior contracting to go the specified place.

(5) breaking the written contract results in referral to the counselor, the administration or the principal.

Evertson and Harris (1997, 1999) developed the Classroom Organization Management Program (COMP). This program suggested that the main factors for effective classroom management were; organizing the classroom (visibility, accessibility, and distractibility), planning and teaching rules and procedures, managing student work (responsibility), maintaining good student behavior, planning and organizing instruction (interaction of teacher and student), and finally, conducting instruction while 
maintaining momentum (participation in teaching).

Pedota (2007) established a series of factors affecting good classroom management. These include; (1) effective management strategies seating plans, attendance, knowledge of the students names, performing administrative tasks while students are working, (2) The physical classroom should be designed to maintain behavioral control, (3) Housekeeping Procedures, (4) Displays - The classroom should be a showcase for student work, as well as posters, magazine covers, charts, maps, and pictures and (5) Instruction -Plan for a variety of instructional experiences and keep students actively involved.

Comparatively, Erdogan et al. (2010) grouped the problems associated with classroom management according to the following schema; lack of motivation, breaking the rules and routines, lack of infrastructure, insufficient time management, ineffective classroom environment, and lack of interaction in classrooms. Alternatively, participants correlated these problems with the following reasons, place and structure of the course in the curriculum, classroom environment, classroom size and lack of hardware, lack of rules, home environment and parents' attitudes, lack of teachers' management skills and students' attitudes. To solve these problems Erdogan (2010) suggested the following guidelines; (1) increasing the teachers pedagogical knowledge, (2) utilizing motivational activities, (3) using punishment in an effective manner, (4) ignoring the misbehavior when it is minor, (5) investigating why the misbehavior occurs, (6) establishing rules, (7) contacting the parents, and

(8) using group cooperation amongst teachers for misbehaving students.

Canter (2010) suggested the importance of classroom rules for classroom management in secondary schools. In sequence these are,

(1) the rules which a student has to always follow, the teacher's directions,

(2) provide positive feedback for students following the rules consistently,

(3) adjustment behavior (methods) of teacher used consistently if the student does not follow the rule, which includes a warning for the first violation, for the second violation a 1-minute detention, for the third violation a call to the parents and for the fourth violation the student is sent to the principal.

Carlson et al. (2011) created a Teacher Classroom Management (TCM) Program. The TCM program involves five content areas: (1) the importance of teacher attention, encouragement, and praise; (2) motivating children through incentives; (3) preventing behavior problems-the proactive teacher; (4) decreasing students" inappropriate behaviors; and (5) building positive relationships with students and problem solving.

From these studies, it can be seen that in the western education system, student misbehaviors are systematically classified. This enables the teachers to sort behaviors according to the required level of behavioral modification. Second, the western system of behavior modification practices continual development and modification. There is continuous research on how to deal with management issues in class and behavioral issues related to classroom management. This research includes subjects like the effects of classroom environment, classroom size and materials, lack of rules, home environment and parental attitudes, lack of teachers' management skills and students' attitudes on student behavior patterns. Furthermore, western instructors are provided with a systematic method for dealing with misbehaviors structured on the seriousness of the misbehavior. Finally, education professionals are 
continually working towards the prevention of misbehavior, and misbehavior management in the classroom.

\section{THE IMPLICATION FOR CLASSROOM MANAGEMENT IN KOREAN SCHOOLS}

The basic outcome is that a set of issues in the classroom has been identified and a structured response established. Currently in Korea, this approach is limited with teachers being left to determine their own discipline methods. This, in turn, leaves teachers in Korea without guidelines on how to deal with misbehaviors. Developing a program to assist in the establishment of strategies that the teacher could apply in creating their own discipline rules will remedy this problem. Moreover, if provided to pre-teachers in their education program, then the procedures can be more systematically defined and applied, which can make discipline in Korean classrooms less equivocal. In Korea, as in most countries, teachers have similar responsibilities to teacher in other countries; however, the understanding and application of classroom management is vastly different. Consequently, it is necessary that student misbehaviors be approached from the classroom management point and if so four main conclusions are possible.

First, students' misbehaviors along with their seriousness in classroom become various types in Korea. As examined earlier in this research (Charles, 2011; Emmer et al., 2003; Kim, 2005a, 2005b; Levin \& Nolan, 2007; Park, 2001), common misbehaviors in Korea and West are making noises during the class, violence to other students, challenging to teachers, sleeping during the class, telling a lie, etc. It is certainly that there are differences in severity of misbehavior in western society such as drug, weapon, which is not occurred in Korean society. This research focuses on common and general misbehaviors of students in school, so it can be stated that misbehaviors occurred in Korean and western school are similar. Consequently, it is necessary to introduce effective foreign program to improve teachers' capability of managing classroom where teachers face difficulties in guiding students.

Second, it is imperative to discuss possible methods for controlling misbehavior following the government ban on corporal punishment. This discussion requires the development of strategies to replace corporal punishment, which requires the unified nationwide development of classroom management programs for teachers in training. This can include the development of a program defining the seriousness of the misbehaviors as has been done elsewhere. Interaction between teachers and students plays an important role in classroom management, which seems to be teacher oriented. Therefore, in order to prevent studnet misbehaviors, obligations and accountability of students can be regulated in detail from the governmental or province government level as done in Canada. Obligations and accountability of students are regulated in Article 150, Educational Act of Saskatchewan Province in Canada (Government of Saskatchewan, 2013). This Law emphasizes that obligation of students is to "present at school" and accountability belongs to the students themselves. On the other hand, Article 12 in Framework Act on education of Korea regulates obligation of students, which covers ethics as learners, following rules of school, prohibition of teachers' educational activities. These are highly general and have 
limitations. Therefore it is necessary to reemphasize the obligations and accountability of students by means of regulations.

Third, there is a requirement for studying the effectiveness of these methods and their use in behavioral management. This requires determining which methods are effective and which are not. This can help to establish an applicable nationwide operational strategy. As well, this strategy should be taught to pre-service and in-service teachers. Currently the lack of instruction in Korea in the education field hinders the development of any effective classroom management program at the instructor level. The result is that pre-service teachers are ill- prepared for behavioral issues and in-service teachers feel inadequate when performing their job.

Finally, social consents on guiding students' misbehaviors are required. School physical punishment has been adapted as one of the effective way to guide and instruct students'misbehaviors that happened in the classroom in Korea; however, since this has been legally prohibited, there are not only some opinions of teachers claiming the reintroduce school physical punishment back to classroom, but the development of effective way of guiding misbehaviors as an alternative to school physical punishment is difficult. Physical punishment is not only administered in school, but is widely adapted in the home, military army, private academic institutions, and sports teams in Korean society. Therefore, our society acknowledges the effectiveness of physical punishment for guiding and controlling students misbehaviors. Furthermore, when every section of society including schools and homes have concerns about how to handle this issue of students misbehaviors and tries to search for alternatives, school physical punishment may disappear and new alternative ways of guiding students misbehaviors will be implemented effectively.

\section{CONCLUSION}

Discipline in Korean schools is based on traditional practices. These practices are derived from family and historical education ideals. Traditionally, in schools, when a student broke the rules, they were hit with a rod, designated as the "Rod of Love". The Enforcement Decree of the Elementary and Secondary Education Act, as defined by the Supreme court of Korea, prescribed that corporal punishment could be only be implemented as a last measure. Thus, the use of corporal punishment in Korean schools was allowed, if not advised by the Supreme Court of Korea, until 2011. However, in March 2011, a newly revised education law came into effect in Korea. Prior to the implementation of the ban on corporal punishment more than $72.7 \%$ of teachers in middle and high school used corporal punishment; however, following the implementation this number dropped to $14.1 \%$ (Yang, 2011).

Globally, corporal punishment is banned in many countries. This has led to the increased discussion of the concept of corporal punishment, and the tendency has been the reduction of corporal punishment at an international level. Worldwide, 117 nation states have totally removed corporal punishment from their education systems, while another seven have enforced limited prohibition. Seventy-four nation states formally enforce corporal punishment within their education systems. Of those countries belonging to the OECD, 29 have banned it, four have implemented partial bans (USA, Australia, Chile, Korea), and one still permits it 
(Mexico).

In Korea, changes in classroom management techniques have little support and limited guidance methods are implemented in the process. The outcome is there is variation in how classrooms are managed, which affects the establishment of accepted discipline techniques. Thus, following the ban on corporal punishment, guidance methods for misbehavior have to be created and implemented. The development of strategies and methods requires establishment of instructional guidelines for teachers in the use of discipline and the stratification of discipline practices within the school system. Thus, there is also the necessity for teacher education, regarding guidelines on when and how to implement disciplinary actions. Currently there are no such programs in Korea. Correspondingly, there are such programs even in the United States, where corporal punishment, is still practiced to a limited extent.

In the United States and Canada, when a child has become a discipline issue, there is a series of steps applied to correct the issue. These involve a gradual progression from teacher-associated discipline to parental involvement. Following the ban on corporal punishment, it is necessary to discuss methods and approaches for classroom behavior issues, and this will require nationwide consensus amongst teachers, administration and perhaps even parents. Finally, in the implementation of discipline in the Korean system, there has to be recognition that discipline is a result of the interaction of all levels of a child's life, parents, teachers, and school principals. With this realization and development, the result is a child who is self-disciplined, and who, over time will become a competent, involved member of society. When this occurs, the requirement for corporal punishment is negated and the students become more self-controlled and can monitor themselves more effectively than corporal punishment.

\section{Reference}

Ahn, M. W.(2007). A study on the cognition of teachers, students, and parents about corporal punishment, Unpublished Master's thesis, Woosuk University, Jeollabuk-do.

Allen, K. P.(2010). Classroom management, bulling, and teacher, The Professional Educator, 27(2), 134 154.

Canter, L.(2010). Assertive discipline : positive behavior management for today's classroom(4th ed.). Bloomington, IN: Solution Tree Press.

Carlson, J. S. - Tiret, H. B. - Bender, S. L. \& Benson, L.(2011). The influence of group training in the incredible years teacher classroom management program on preschool teachers' classroom management strategies, Journal of Applied Psychology, 27(2), 134 154.

Charles, C. M.(2011). Building classroom discipline (10th ed.). Boston: Allyn and Bacon.

Choi, T. J.(2013). Teachers' perception and attitude on corporal punishment. Journal of Fisheries and Marine Science Education, 25(2), 375 392.

Doyle(1986). 'Classroom management techniques'. In Wittrock, C. (ed.) Handbook of research on teaching (3rd ed.). New York: Macmillan Publishing Co.

Dupper, D. R. \& Dingus, A. E. M.(2008). Corporal punishment in U.S. public schools: A continuing challenge for school social workers. Children \& Schools, 30(4), 243 249.

Emmer, E. T. - Evertson, C. M. \& Worsham, M. E. (2003). Classroom management for secondary teachers (6th ed.). Boston: Allyn and Bacon.

Erdogan, M. $\cdot$ Kursun, E. - TanSisman, G. · Saltan, F. - Gok, A. \& Yildiz, I.(2010). Problems, reasons, and solutions: a case of information technologies. EducationScience: Theory \& Practice, 10(2), 881 891.

Evertson, C. M. \& Harris, A. H.(1997). COMP-A 
workbook manual for elementary teachers(5th ed.). TN: Vanderbilt University.

Evertson, C. M. \& Harris, A. H. (1999). Support for managing learning-center classrooms. In $\mathrm{H}$. J. Freiberg (Ed.), Beyond behaviorism: Changing the classroom management paradigm, Boston: Allyn and Bacon.

Global Initiative to End All Corporal Punsihment of Children. (Global Initiative)(2012). Global progress towards prohibiting all corporal punishment. Retrieved from

http://www.endcorporalpunishment.org/pages/pdfs/char ts/Chart-Global.pdf

Government of Saskatchewan(2013). The Education Act, 1995. Retrieved from

http://www.qp.gov.sk.ca/documents/English/Statutes/St atutes/E0-2.pdf

Guardino, C. A. \& Fullerton, E.(2010). Changing behaviors by changing the classroom, Teaching exceptional children, 42(6), 8 13.

Jeong, H. S.(2011). A study on elementary teacher'perspective of physical punishment in the school setting, Unpublished Master's thesis, The University of Suwon, Gyeonggi-do.

Jeong, Y. H.(1987). Confucian ethics education of Seong-Kyun-Kwan in the early Joseon Dynasty, Unpublished Master's thesis, Dongguk University, Seoul.

Jones, V. F. \& Jones, L. S.(2001). Comprehensive classroom management: creating communities of support and solving problems (6th ed.). Boston: Allyn and Bacon.

Jo, S. H. • Kim, H. J. \& Pyo, S. Y.(2012). An analysis of the perception on corporal punishment among teachers, students, and parents and legal, The Journal of Law of Education, 24(2), 67 91.

Kim, D. H.(2005a). The difference in severity and frequency of classroom discipline problems between male and female students in middle school classrooms, Journal of Fisheries and Marine Science Education, 17(1), 35 47.

Kim, D. H.(2005b). The difference of severance and frequency on the classroom discipline problem between academic high school and vocational high school. The Journal of Education Administration, 23(1), 261 280.
Kim, H. S.(1993). A study on yes or not to justice of punishment, The Journal of Law of Education, $5,85 \sim 111$.

Kim, H. S. \& Hwang, M. H.(2009). Development of the student problem behavior checklist for elementary school teachers, The Journal of Elementary Education, 22(2), 123 138.

Kim, I. H. \& Kim, Y. B.(2006). KEDI POLL 2006, Korean Education Development Institute.

Kim, J. H.(2002). Comparative study on the perception of student punishment among teachers, parents and pupils, Unpublished Master's thesis, Dongguk University, Seoul.

Kim, S. R.(2004). An analysis of the perception of elementary school students and teachers on the discipline effectiveness according to each misbehavior, Unpublished Master's thesis, Busan National University of Education, Busan.

Koo, K. H., \& Yoo, S. H.(2012). An analysis of school life satisfaction according to the consensus of class teacher's discipline style perceive by between teacher and student, Journal of Fisheries and Marine Science Education, 24(6), 977 988.

Kwon, I. T.(1999). Corporal punishment for students in major developed countries and its implications for Korean school, The Journal of Korean Teacher Education, 16(2), 195 216.

Law and Legal Research(2013). State Laws. Retrieved from http://law.onecle.com/arizona/education/15-843.html; http://law.onecle.com/georgia/20/20-2-731.html; http://law.onecle.com/new-jersey/18a-education/6-1.ht $\mathrm{ml}$.

Lee, J. H.(1995). The historical study on the corporal education department of industrial education, Society Science Review, 5, 251 278.

Levin, J. \& Nolan, J. F.(2007). Principles of classroom management: A professional decision-making model (5th ed.). Boston: Pearson/Allyn and Bacon.

Lee, W. T.(2010). The legal analysis of limitation for teacher's corporal punishment on students. Journal of Fisheries and Marine Science Education, 22(3), 445 459.

Ministry of Government Legislation(2013). Enforcement Decree of the Elementary and Secondary Education Act (1998, 2011). Retrieved from 
http://www.moleg.go.kr/english/korLawEng?pstSeq $=52201 \& \mathrm{rctPstCnt}=3 \&$ searchCondition $=$ Tt $1 \&$ searchKe yword=Elementary+and+Secondary+Education

Namgung, J. Y. - Kim, C. H., \& Woo, M. S.(2012). KEDI POLL 2012, Korean Education Development Institute.

Namgung, J. Y. \& Woo, M. S.(2010). KEDI POLL 2010, Korean Education Development Institute.

Namgung, J. Y. \& Woo, M. S.(2011). KEDI POLL 2011, Korean Education Development Institute.

Nation Culture Propulsion Committee. (1982). Collection book of Yulgok I, II. Nation Culture Bookcase Publication Committee.

Park, B. Y.(1997). Classroom management, Seoul: Hakjisa.

Park, B. Y.(2001). Discipline, Seoul: Hakjisa.

Park, C. K.(2011). The justification and permissible range of corporal punishment in school, Korean Criminological Review, 22(1), 39-64.

Park, H. J. \& Yeon, E. K.(2003). An analytical study on the life and culture of Korean secondary school students, Korean Education Development Institute.

Pedota, P.(2007). Strategies for effective classroom management in the secondary setting, Clearing House, 80(4), 163 168.

Public Agenda(2004). Teaching in Wrnipted: Do discipline policies in today's public schools foster the common good? New York, NY: Author. Retrieved from http://commongood.org//assets/ attachments/22.pdf

Savage, T. V. \& Savage, M. K.(2010). Successful classroom management and discipline: teaching self-control and responsibility (3rd ed.). Los Angeles: SAGE.

Seoul Metropolitan Office of Education(2012). Education plan for student life in 2012, Seoul Metropolitan Office of Education.

Sohn, H. K.(2003). Alternatives to teacher-student corporal punishment: comparison between students' and teachers' perceptions, The Journal of Research in Education, 19, 111-133.

Sung, K. S. • Kim, Y. \& Kim, S. U.(1999). KEDI POLL 1999, Korean Education Development Institute.

The Editing Board of Education Dictionary(1989). The great dictionary of education, Education book press.

The Korean Federation of Teachers' Association (2010). Teacher survey results, Press release (2010.7.21).

The Korean Language Society(1992). The Urimal large dictionary, Seoul: Emungak Inc.

Yang, S. Y.(2011). A study on the perception of teachers and students on banning coporal punishment and alternatives for it, Unpublished Master's thesis, Kunkuk University, Seoul.

Yeonhap News(2011). "National Human Rights Commission of Korea: The indirectness corporal punishment introduction is not desirable." Yeonhap News Agency, March 3. Retrieved from http://www.yonhapnews.co.kr/bulletin/2011/03/02/020 0000000AKR20110302217851004.HTML?did=1179m.

Yoo, K. S. • Namgung, J. Y. \& Kim, I. H.(2008). KEDI POLL 2008, Korean Education Development Institute.

Yoo, S. S.(2011). An analysis of the discourse on students human right (SHR). The Journal of Politics of Education, 18(2), 235 257.

Yoon, S. J. \& Kang, S. H.(2011). The relationships of perceived attachment, social support and problem behavior of middle school students, Journal of Fisheries and Marine Science Education, 23(4), 582 595.

Yun, G. I.(2005). Kyonggukdaejon, Seoul: Shinseowon Inc.

- 논문접수일 : 2013년 08월 01일

- 심사완료일 : 1차 - 2013년 10월 10일

- 게재확정일 : 2013년 10월 14일 